\title{
MENINGKATKAN KEMAMPUAN PEMECAHAN MASALAH DAN PENALARAN MATEMATIS DENGAN LAPS-HEURISTIC DAN PENDEKATAN OPEN-ENDED
}

\author{
Moch. Rasyid Ridha \\ Universitas Langlangbuana, Jalan Karapitan No.116 Bandung, rasyidridha48@yahoo.com
}

\begin{abstract}
ABSTRAK
Artikel ini melaporkan temuan satu eksperimen dengan desain pretest-postest dengan kelompok kontrol dan menerapkan pendekatan open-ended dengan model Logan avenue problem solving (LAPS)-Heuristic, untuk menelaah kemampuan pemecahan masalah dan penalaran matematis siswa SMA. Subjek penelitian ini adalah 88 siswa SMA kelas $X$ di Bandung. Instrumen penelitian terdiri dari tes kemampuan pemecahan masalah dan penalaran matematis. Berdasarkan analisis data menggunakan SPSS 2.0.0 dan Microsoft Excel 2013, penelitian menemukan: pencapaian dan peningkatan kemampuan pemecahan masalah dan penalaran matematis siswa yang memperoleh model Logan Avenue Problem Solving (LAPS)Heuristic dan Pendekatan Open-Ended lebih baik daripada pencapaian dan peningkatan kemampuan siswa yang memperoleh pendekatan konvensional. Penelitian juga menemukan adanya hubungan sedang antara kemampuan pemecahan masalah dan penalaran matematis.
\end{abstract}

Kata kunci: Model Logan Avenue Problem Solving (LAPS)-Heuristic, Pendekatan Open-Ended, Pemecahan Masalah Matematis dan Penalaran Matematis.

\section{ABSTRACT}

This article reports the findings from an experimental pretest-posttest control group design conducted by using open-ended approach with Logan avenue problem solving (LAPS)-Heuristic model to investigate students' mathematical problem solving and reasoning abilities. The study involved 88 grade-10 students from SMA in Bandung. The instrumens of this study are mathematical problem solving test and mathematical reasoning test. By using SPSS 2.0.0 and Microsoft Excel 2013, the study found the openended approach with Logan avenue problem solving (LAPS)-Heuristic was able to improve students' mathematical problem solving and reasoning abilities better than that of conventional approach. Students' mathematical problem solving and reasoning abilities were classified as mediocore. Furthermore, the study found there was medium correlation between mathematical problem solving and reasoning abilities.

Keywords: Logan Avenue Problem Solving (LAPS)-Heuristic Model, OpenEnded Approach, Mathematical Problem Solving and Reasoning Abilities.

How to Cite: Ridha, M. R. (2017). Meningkatkan Kemampuan Pemecahan Masalah dan Penalaran Matematis dengan Laps-heuristic dan Pendekatan Open-ended. Mathline: Jurnal Matematika dan Pendidikan Matematika, Vol.2, No.1, 91-108.

\section{PENDAHULUAN}

Matematika merupakan salah satu cabang ilmu pengetahuan yang mempunyai peranan dalam perkembangan ilmu pengetahuan dan teknologi (IPTEK). Sumarmo (2004) 
menyatakan bahwa matematika mempunyai peranan penting, dimulai dari peran yang sederhana sampai peran yang sangat kompleks, memberikan sumbangan dalam ilmu pengetahuan lainnya dan dalam kehidupan sehari-hari. Itulah sebabnya mata pelajaran matematika diajarkan dari jenjang sekolah dasar sampai pendidikan tinggi. Sebagai bidang disiplin ilmu yang diajarkan disetiap jenjang pendidikan, tentu saja pembelajaran matematika mempunyai tujuan yang ingin dicapai.

Peraturan Menteri Pendidikan Nasional Republik Indonesia Nomor 22 tahun 2006 tentang standar isi (Permendiknas, 2006) disebutkan bahwa pembelajaran matematika bertujuan agar peserta didik mempunyai kemampuan sebagai berikut: 1) Memahami konsep matematika, menjelaskan keterkaitan antar konsep atau algortima, secara luwes, akurat efisien, dan tepat waktu dalam pemecahan masalah; 2) menggunakan penalaran pada pola dan sifat, melakukan manipulasi matematika dalam membuat generalisasi, menyusun bukti, atau menjelaskan gagasan dan pernyataan matematika; 3) memecahkan masalah yang meliputi kemampuan memahami masalah, merancang model matematika, menyelesaikan model dan menafsirkan solusi yang diperoleh; 4) mengkomunikasikan gagasan dan simbol, tabel, diagram, atau media lain untuk memperjelas keadaan atau masalah; 5) memiliki sikap menghargai kegunaan matematika dalam mempelajari masalah, serta sikap ulet dan percaya diri dalam pemecahan masalah.

Kemampuan-kemampuan tersebut sejalan dengan kemampuan-kemampuan matematis yang disusun oleh National Council of Teachers of Mathematics (NCTM). Kemampuan-kemampuan tersebut yang dirumuskan NCTM (2000) terdiri dari: komunikasi matematis (mathematical communication), penalaran matematis (mathematical reasoning), pemecahan masalah matematis (mathematical problem solving), koneksi matematis (mathematical connection) dan pembentukan sikap positif terhadap matematika (positive attitudes toward mathematics).

Dilihat dari tujuan pembelajaran matematika di atas, kemampuan pemecahan masalah dan penalaran matematis siswa merupakan hal yang sangat besar pengaruhnya bagi tercapainya tujuan pembelajaran secara keseluruhan. Pemecahan masalah sebagai tujuan pembelajaran atau kemampuan yang harus dicapai setelah pembelajaran merupakan aktivitas dimana penyelesaian dari suatu masalah belum diketahui atau tidak segera ditemukan. Secara garis besar pula penalaran matematika terdiri terdiri dari dua jenis yaitu penalaran induktif dan penalaran deduktif. 
Menurut Sumarmo (2004), kesulitan yang dialami oleh siswa dipengaruhi oleh banyak faktor, diantaranya adalah bobot belajar yang guru berikan kepada siswa tidak sebanding dengan kemampuan siswa. Disamping kemampuan siswa yang beragam juga merupakan faktor yang mempengaruhi kesulitan belajar siswa, banyaknya beban belajar yang harus siswa hadapi memberikan efek yang cukup besar bagi kesulitan belajar. Selanjutnya Hudoyo (2003), bahwa pembelajaran yang ideal seharusnya dapat mengakomodasi kepentingan semua siswa, sehingga siswa dapat mengikuti pembelajaran dengan baik dan mampu mewujudkan kinerja terbaik mereka selama proses pembelajaran. Dalam kenyataan tersebut, perlu adanya kerjasama antara guru dan siswa sehingga memunculkan pembelajaran yang baik. Guru harus mampu mengakomodir kemampuan siswa, sehingga dapat menciptakan suatu pembelajaran yang harmonis.

Suherman (2003), mengemukaakn bahwa melalui cara belajar yang membuka wawasan siswa, akan membuat siswa tersebut dapat memperoleh hasil belajar matematika yang lebih baik. Melatih, mengasah dan mengembangkan kemampuan berpikir siswa dengan jalan menumbuhkan daya kecakapan yang mereka miliki mempunyai kemungkinan yang kecil, jika model pembelajaran dan pendekatan yang diterapkan guru adalah model klasik (konvensional). Untuk itu, guru harus mempunyai inovasi pembelajaran yang menarik untuk membuat kegiatan pembelajaran di kelas lebih menarik, sehingga siswa dapat mengikuti pembelajaran dengan baik.

Berdasarkan analisis pendahuluan terhadap pemecahan masalah dan penalaran matematis siswa, dipandang perlu untuk mengembangkan suatu model pembelajaran yang dapat meningkatkan pemahaman konsep esensial itu. Sebagai kerangka umum dalam menghadapi suatu masalah dalam matematika adalah kemampuan mengidentifikasi faktafakta yang diberikan (data), dan merumuskan apa yang ditanyakan dalam masalah itu (target akhir). Untuk dapat menentukan target akhir berdasarkan data yang diberikan, diperlukan kemampuan mengelaborasi dengan menerapkan konsep esensial yang relevan terhadap data yang diberikan. Tidak sedikit masalah dalam matematika dapat lebih mudah diselesaikan dengan menambahkan kemampuan dalam merumuskan suatu kondisi (target antara) sehingga berdasarkan suatu konsep esensial yang relevan tiba pada target akhir yang ditanyakan.

Terdapat banyak alternatif model pembelajaran yang dapat diterapkan, salah satu model pembelajaran yang dirasa efektif adalah penerapan model pembelajaran Logan Avenue Problem Solving (LAPS)-Heuristic dengan menggunakan pendekatan Open-Ended, 
yang merupakan inovasi baru gaya mengajar dengan memunculkan permasalahan terbuka bagi siswa (Suherman, 2003), yang diharapkan dapat mengembangkan kemampuan pemecahan masalah dan penalaran matematis siswa, sehingga hasil belajar yang dicapai dapat meningkat pula.

Heuristik adalah suatu penuntun berupa pertanyaan-pertanyaan yang diperlukan dalam menyelesaikan suatu masalah. Heuristik berfungsi mengarahkan pemecah masalah (dalam hal ini siswa) untuk menemukan suatu solusi dari masalah yang diberikan. Polya (1973), menyatakan : “A heuristic is a plan of attack. A heuristic is designed to help problem solvers approach, understand, and attempy to solve a problem". Logan Avenue Elementary School (Emporia, Kansas) mengusulkan suatu heuristik untuk menyelesaikan suatu masalah dalam matematika. Heuristic itu mencakup: "(1) what is the problem?; (2) what are the alternatives?; (3) what are the advantages or disadvantages?; (4) what is the solutions?; (5) how well's it working?" Selanjutnya heuristic itu disebut Logan Avenue Problem Solving Heuristic (LAPS-Heuristic).

Pendekatan Open-Ended adalah pendekatan terbuka yang memberikan kebebasan individu untuk mengembangkan berbagai cara dan strategi pemecahan masalah sesuai dengan kemampuan masing-masing peserta didik (Suherman, 2003), kemudian Suherman (2004) mengatakan "Orientasi Open Ended terletak pada proses bukan pada hasil semata, proses ini menyangkut strategi, metode dan cara". Pendekatan Open Ended memberikan ruang yang cukup bagi peserta didik untuk mengeksplorasi permasalahan sesuai kemampuan, bakat, dan minatnya, sehingga peserta didik yang memiliki kemampuan yang lebih tinggi dapat berpartisipasi dalam berbagai kegiatan matematika, dan peserta didik dengan kemampuan lebih rendah masih dapat menikmati kegiatan matematika sesuai dengan kemampuannya.

Dalam penelitian ini, selain dari aspek pembelajaran, ditinjau pula aspek kemampuan awal matematis (KAM) siswa yang diperoleh dari data nilai tes formatif siswa. Tujuannya yakni untuk melihat apakah implementasi model dan pendekatan pembelajaran yang digunakan dapat merata di semua kategori KAM (tinggi, sedang dan rendah), sehingga penelitian ini dapat digeneralisasi untuk semua tingkatan kemampuan.

Dengan memperhatikan uraian di atas, keperluan untuk melakukan penelitian yang berfokus pada pengembangan pendekatan pembelajaran yang dapat meningkatkan kemampuan penalaran dan kemampuan pemecahan masalah matematis siswa, yaitu pembelajaran matematika menggunakan model pembelajaran LAPS-Heuricstic dengan 
pendekatan Open-Ended dipandang penting. Oleh karena itu, penulis mencoba melakukan penelitian yang terkait dengan pembelajaran matematika menggunakan model pembelajaran LAPS-Heuristic dengan pendekatan Open Ended, serta kemampuan yang akan diteliti adalah kemampuan pemecahan masalah dan penalaran matematis.

Berdasarkan rumusan masalah di atas, tujuan dari penelitian ini adalah menelaah peningkatan kemampuan pemecahan masalah dan penalaran matematis siswa yang memperoleh pembelajaran melalui model pembelajaran LAPS-Heuristic dengan pendekatan Open-Ended lebih baik daripada siswa yang memperoleh pembelajaran konvensional. Kemudian penelitian ini bertujuan pula untuk melihat perbedaan peningkatan kemampuan pemecahan masalah dan penalaran matematis siswa menggunakan model LAPS-Heuristic dengan pendekatan Open-Ended dilihat dari kemampuan siswa (tinggi,sedang dan rendah). Selain itu, penelitian ini juga bertujuan untuk menelaah korelasi yang signifikan antara kemampuan pemecahan masalah dan penalaran matematis siswa setelah pembelajaran menggunakan model LAPS-Heuristic dengan pendekatan Open-Ended.

\section{METODE PENELITIAN}

Penelitian ini merupakan penelitian kuasi eksperimen karena subjek pada penelitian ini tidak dikelompokkan secara acak, tetapi peneliti menerima keadaan subjek penelitian apa adanya. Dalam penelitian ini diambil dua kelas sebagai sampel, yaitu kelas eksperimen yang diberi treatment berupa pembelajaran dengan menggunakan model pembelajaran Logan Avenue Problem Solving-Heuristic dengan pendekatan open-ended selanjutnya ditulis dengan model pembelajaran LAPS-Heuristic dengan pendekatan Open-Ended dan kelas kontrol menggunakan pembelajaran konvensional. Adapun desain penelitian ini menggunakan desain kelompok kontrol non-ekuivalen (Ruseffendi, 2006) berikut:

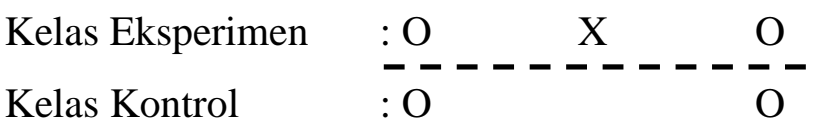

Keterangan:

$\mathrm{O} \quad$ : pretes dan postes tes kemampuan pemecahan masalah dan penalaran matematis

$\mathrm{X}$ : Pembelajaran matematika menggunakan pembelajaran LAPS-Heuristic dengan pendekatan open-ended 
: Subjek tidak dikelompokkan secara acak

Populasi dalam penelitian ini adalah seluruh siswa kelas X Salah satu SMA Negeri di Kabupaten Bandung Provinsi Jawa Barat tahun ajaran 2016/2017. Peringkat sekolah SMA Negeri yang dijadikan subjek nanti termasuk dalam klasifikasi sekolah sedang. Pemilihan tempat penelitian dengan klasifikasi sekolah sedang bertujuan meminimalisir pengaruh luar dalam pelaksanaan penelitian seperti kemampuan siswa yang tinggi pada sekolah klasifikasi tinggi dan kemampuan yang rendah pada sekolah klasifikasi rendah.

Cara memperoleh data dalam penelitian ini, digunakan satu jenis instrumen, yaitu instrumen tes, tetapi digunakan 2 jenis instrumen tes. Instrumen tes berupa seperangkat soal tes untuk mengukur kemampuan pemecahan masalah matematis dan kemampuan penalaran matematis.

\section{Tes Kemampuan Pemecahan Masalah dan Penalaran Matematis}

Instrumen tes kemampuan pemecahan masalah dikembangkan dari materi pembelajaran yang akan diteliti. Tes yang digunakan untuk mengukur kemampuan pemecahan masalah matematis siswa yaitu soal berbentuk uraian. Dalam penyusunan soal tes, diawali dengan penyusunan kisi-kisi soal yang dilanjutkan dengan menyusun soal beserta alternatif kunci jawaban masing-masing butir soal.

Tes kemampuan pemecahan masalah matematis terdiri dari seperangkat soal pretes dan postes yang dibuat relatif sama. Pretes diberikan dengan tujuan untuk mengetahui kesamaan kemampuan awal siswa pada kedua kelas dan digunakan sebagai tolak ukur peningkatan kemampuan pemecahan masalah matematis sebelum mendapatkan perlakuan, sedangkan postes diberikan dengan tujuan untuk mengetahui perolehan kemampuan pemecahan masalah matematis dan ada tidaknya peningkatan yang signifikan setelah mendapatkan perlakuan yang berbeda. Jadi, pemberian tes pada penelitian ini bertujuan untuk mengetahui pengaruh dari suatu perlakuan dalam hal ini pembelajaran LAPSHeuristic dengan pendekatan open-ended terhadap kemampuan pemecahan masalah matematis siswa.

Adapun strategi pemecahan masalah yang dikemukakan Polya (Ruseffendi 2006), terangkum dalam empat langkah yang ditempuh dalam pemecahan masalah dan acuan dalam penyususnan pedoman penskoran sebagai berikut : 

a. Mamahami Masalah (Understanding the problem solving);
b. Merencanakan Penyelesaian (Devising a plan)
c. Melaksanakan Rencana (Carrying out the plan)
d. Memeriksa Proses dan Hasil (looking back)

\section{Tes Kemampuan Penalaran Matematis}

Instrumen tes kemampuan penalaran matematis dikembangkan dari materi pembelajaran yang akan diteliti. Tes yang digunakan untuk mengukur kemampuan penalaran matematis siswa yaitu soal berbentuk uraian. Dalam penyusunan soal tes, diawali dengan penyusunan kisi-kisi soal yang dilanjutkan dengan menyusun soal beserta alternatif kunci jawaban masing-masing butir soal.

Tes kemampuan penalaran matematis masing-masing terdiri dari seperangkat soal pretes dan postes yang dibuat relatif sama. Pretes diberikan dengan tujuan untuk mengetahui kesamaan kemampuan awal siswa pada kedua kelas dan digunakan sebagai tolak ukur peningkatan kemampuan penalaran matematis sebelum mendapatkan perlakuan, sedangkan postes diberikan dengan tujuan untuk mengetahui perolehan kemampuan pemecahan masalah dan penalaran matematis dan ada tidaknya peningkatan yang signifikan setelah mendapatkan perlakuan yang berbeda. Jadi, pemberian tes pada penelitian ini bertujuan untuk mengetahui pengaruh dari suatu perlakuan dalam hal ini pembelajaran LAPS-Heuristic dengan pendekatan open-ended terhadap kemampuan penalaran matematis siswa.

Dalam penelitian ini indikator kemampuan penalaran matematis yang digunakan adalah kemampuan penalaran deduktif dan induktif, dengan indikator sebagai berikut:

a. Melaksanakan perhitungan berdasarkan rumus dan aturan tertentu.

b. Penalaran transduktif: proses penarikan kesimpulan dari pengamatan terbatas diberlakukan pada kasus tertentu.

c. Menggunakan pola hubungan untuk menganalisis situasi, dan menyusun konjektur.

d. Penalaran logis, mampu mengidentifikasi alasan logis dari serangkaian informasi atau kasus yang diperlukan untuk menyelesaikan soal.

e. Memberikan penjelasan terhadap model, fakta, sifat, hubungan atau pola yang ada.

f. Memperkirakan jawaban, solusi atau kecenderungan: interpolasi dan ekstrapolasi.

Sebelum tes kemampuan pemecahan masalah dan penalaran matematis digunakan dilakukan uji coba dengan tujuan untuk mengetahui apakah soal tersebut sudah memenuhi persyaratan validitas, reliabilitas, tingkat kesukaran dan daya pembeda. Soal tes 
kemampuan pemecahan masalah matematis ini diujicobakan pada siswa kelas XI yang telah menerima materi pada kelas X.

Teknik pengumpulan data pada penelitian ini dilakukan dengan melakukan tes, yaitu pretes dan postes, untuk mengetahui peningkatan kemampuan pemecahan masalah dan penalaran matematis siswa pada kelas eksperimen dan kelas kontrol. Sebelum diberikan pretes, siswa dikelompokkan berdasarkan kategori kemampuan awal matematika (KAM). Pengelompokan dilakukan bertujuan untuk mengetahui pengetahuan siswa sebelum pembelajaran dilakukan dan digunakan sebagai penempatan siswa berdasarkan kemampuan awal matematisnya. KAM siswa dikelompokkan menjadi tiga kategori yaitu KAM kategori tinggi, sedang dan rendah. Berikut adalah pengelompokkan siswa berdasarkan kategori tinggi, sedang, dan rendah pada kelas eksperimen dan kontrol:

Tabel 1. Banyak Siswa Berdasarkan Kategori KAM

\begin{tabular}{cccc}
\hline Kelompok & Kelas Eksperimen & Kelas Kontrol & Total \\
\hline Tinggi & 7 & 7 & 14 \\
Sedang & 30 & 31 & 61 \\
Rendah & 7 & 6 & 13 \\
Total & 44 & 44 & 88 \\
\hline
\end{tabular}

Selanjutnya setelah diperoleh skor pretes dan postes, untuk mengetahui besar peningkatan kemampuan pemecahan masalah dan penalaran matematis siswa sebelum sampai setelah mendapat pembelajaran menggunakan model pembelajaran LAPS-Heuristic dengan pendekatan Open-Ended baik pada siswa kelas eksperimen dan siswa kelas kontrol dihitung dengan menggunakan rumus gain ternormalisasi yang dikemukakan oleh Meltzer (2002), sebagai berikut:

$$
\text { Gain ternormalisasi }(\mathrm{g})=\frac{\text { skor postes }- \text { skor pretes }}{\text { skor maksimal ideal }- \text { skor pretes }}
$$

Setelah data hasil tes berpikir kritis matematis dan disposisi matematis baik pretes maupun postes terkumpul maka akan dilakukan analisis menggunakan bantuan software SPSS 2.0.0 for windows. Pengolahan data diawali dengan menguji prasayarat statistik yang diperlukan sebagai dasar pengujian hipotesis, yaitu uji normalitas sebaran data dan uji homogenitas variansi untuk tiap kelas. Kemudian ditentukan jenis pengujian hipotesis sesuai dengan permasalahan.

Uji normalitas dilakukan untuk mengetahui apakah data pada dua kelompok sampel yang diteliti berasal dari populasi yang berdistribusi normal atau tidak. Uji normalitas yang digunakan adalah uji Kolmogorov Smirnov dengan taraf signifikansi 5\%. Uji homogenitas 
dilakukan untuk mengetahui kesamaan antara dua variansi populasi. Uji homogenitas yang digunakan adalah uji Levene dengan taraf signifikansi 5\%. Selanjutnya akan kita gunakan uji hipotesis. Terdapat 3 jenis uji yang digunakan yaitu iju kesamaan dua rerata, uji ANOVA satu jalur dan uji korelasi

Uji kesamaan dua rerata yang digunakan tergantung dari hasil uji normalitas data dan uji homogenitas variansi data. Jika data berdistribusi normal, uji perbedaan dua rerata menggunakan uji statistik parametrik, yaitu uji Independent-Samples T Test (Uji-t). Jika variansi kedua kelompok data homogen, nilai signifikansi yang diperhatikan adalah nilai pada baris "Equal variances assumed", sedangkan jika variansi kedua kelompok homogen, maka nilai signifikansi yang diperhatikan yaitu nilai pada baris "Equal variances not assumed". Selanjutnya, jika terdapat minimal satu data yang tidak berdistribusi normal, maka uji perbedaan dua rerata menggunakan uji nonparametrik, yaitu Uji Mann-Whitney U. untuk uji dua pihak, kriteria penerimaan $\mathrm{H}_{\mathrm{o}}$ bila nilai signifikansi/2 $>\propto$

Uji perbedaan rata-rata skor n-gain kemampuan pemecahan masalah dan penalaran matematis siswa yang menggunakan model pembelajaran LAPS-Heuristic dengan pendekatan Open-Ended berdasarkan kategori kemampuan awal matematis dilakukan dalam rangka menjawab pertanyaan apakah terdapat perbedaan peningkatan kemampuan pemecahan masalah dan penalaran matematis siswa yang menggunakan model pembelajaran LAPS-Heuristic dengan pendekatan Open-Ended berdasarkan kategori KAM. Untuk menjawab rumusan masalah tersebut, uji statistik yang digunakan adalah ANOVA satu jalur, namun sebelumnya harus dilakukan dulu uji normalitas, dan homogenitas.

\section{HASIL DAN PEMBAHASAN}

Data kuantitatif diperoleh melalui tes kemampuan pemecahan masalah dan penalaran matematis di awal dan akhir pembelajaran. Data tersebut didapat dari 88 orang siswa yang terdiri dari 44 siswa kelas eksperimen (pembelajaran model LAPS-Heuristic dengan pendekatan Open-Ended) dan 44 siswa kelas kontrol (pembelajaran konvensional). Dari kelas eksperimen dan kelas kontrol dikelompokkan dalam siswa berkemampuan tinggi, sedang dan rendah.

Kemampuan pemecahan masalah dan penalaran matematis diperoleh melalui pretes dan postes. Dari skor pretes dan postes selanjutnya dihitung gain ternormalisasi (N-gain) kemampuan pemecahan masalah dan penalaran matematis siswa pada kelas eksperimen yang mendapat pembelajaran model LAPS-Heuristic dengan pendekatan Open-Ended 
maupun kelas kontrol yang mendapat pembelajaran konvensional. Hasil skor pretes, postes dan N-gain dapat dilihat pada Lampiran. Berikut ini merupakan deskripsi pretes, postes dan $\mathrm{N}$-gain kemampuan pemecahan masalah dan penalaran matematis siswa pada kelas ekperimen dan kelas kontrol.

Tabel 2. Statistik Deskriptif Kemampuan Pemecahan Masalah dan Penalaran Matematis Keseluruhan Eksperimen dan Kontrol

\begin{tabular}{cccccccc}
\hline \multirow{2}{*}{ Kemampuan } & \multirow{2}{*}{$\begin{array}{c}\text { Data } \\
\text { Statistik }\end{array}$} & \multicolumn{3}{c}{ Kelas Esperimen $($ LAPS) } & \multicolumn{3}{c}{$\begin{array}{c}\text { Kelas Kontrol } \\
\text { (Konvensional) }\end{array}$} \\
\cline { 3 - 8 } & $\bar{x}$ & 5,45 & 12,39 & 0,48 & 5,70 & 11,18 & 0,30 \\
Pemecahan & $\mathrm{S}$ & 1,17 & 2,37 & 0,14 & 1,05 & 2,31 & 0,14 \\
Masalah & $\bar{x}$ & 10,66 & 22,39 & 0,55 & 11,11 & 18,95 & 0,38 \\
Penalaran & $\mathrm{S}$ & 0,96 & 3,36 & 0,16 & 1,26 & 3,68 & 0,15 \\
& Skor Maksimum Ideal Pemecahan Masalah Matematis $=20$ & \\
& \multicolumn{3}{c}{ Skor Maksimum Ideal Penalaran Matematis = 32 } \\
\hline
\end{tabular}

Tabel 3. Statistik Deskriptif Kemampuan Pemecahan Masalah dan Penalaran Matematis Kelas Eksperimen Berdasarkan KAM

\begin{tabular}{cccccccc}
\hline \multirow{2}{*}{$\begin{array}{c}\text { Kategori } \\
\text { KAM }\end{array}$} & \multirow{2}{*}{$\begin{array}{c}\text { Data } \\
\text { Statistik }\end{array}$} & \multicolumn{2}{c}{$\begin{array}{c}\text { Kemampuan Pemecahan } \\
\text { Masalah Matematis }\end{array}$} & \multicolumn{3}{c}{$\begin{array}{c}\text { Kemampuan Penalaran } \\
\text { Matematis }\end{array}$} \\
\cline { 3 - 8 } & & Pretes & Postes & N-gain & Pretes & Postes & N-gain \\
\hline \multirow{2}{*}{ Tinggi } & $\bar{x}$ & 6,86 & 16,71 & 0,75 & 12,43 & 27,14 & 0,75 \\
& $\mathrm{~s}$ & 0,69 & 0,95 & 0,07 & 0,53 & 0,90 & 0,05 \\
\multirow{3}{*}{ Sedang } & $\bar{x}$ & 5,53 & 12,07 & 0,45 & 10,83 & 21,9 & 0,52 \\
& $\mathrm{~s}$ & 0,78 & 1,11 & 0,08 & 0,99 & 2,06 & 0,10 \\
\multirow{2}{*}{ Rendahy } & $\bar{x}$ & 3,71 & 9,43 & 0,35 & 8,71 & 18,14 & 0,4 \\
& $\mathrm{~s}$ & 0,50 & 0,82 & 0,05 & 0,58 & 1,71 & 0,05 \\
& Skor Maksimum Ideal Pemecahan Masalah Matematis $=20$ & \\
& \multicolumn{7}{c}{ Skor Maksimum Ideal Penalaran Matematis = 32 } \\
\hline
\end{tabular}

Berdasarkan Tabel 2 di atas terlihat bahwa rerata skor pretes kemampuan pemecahan masalah matematis kelas eksperimen menggunakan pembelajaran model LAPS-Heuristic dengan pendekatan Open-Ended sebesar 5,45 sedangkan rerata pretes kelas konvensional sebesar 5,7. Data pretes semua kategori KAM pada kelas ekperimen dan kelas kontrol relatif sama. Berdasarkan data tersebut baik ditinjau secara keseluruhan siswa maupun secara kategori KAM dapat disimpulkan bahwa kemampuan awal siswa pada dua kelas adalah sama.

Berdasarkan Tabel 3 di atas diperoleh rerata gain kemampuan pemecahan masalah matematis siswa apabila ditinjau dari kategori KAM, nampak bahwa KAM tinggi siswa kelas eksperimen mendapat rerata sebesar 0,75 dan siswa kelas kontrol sebesar 0,65. Data 
tersebut menunjukkan bahwa gain kedua kelas relatif berbeda, yaitu tinggi untuk kelas eksperimen dan sedang untuk kelas kontrol, sehingga pembelajaran model LAPS-Heuristic dengan pendekatan Open-Ended memberikan kontribusi yang cukup baik dalam perkembangan kemampuan pemecahan masalah matematis siswa pada KAM tinggi.

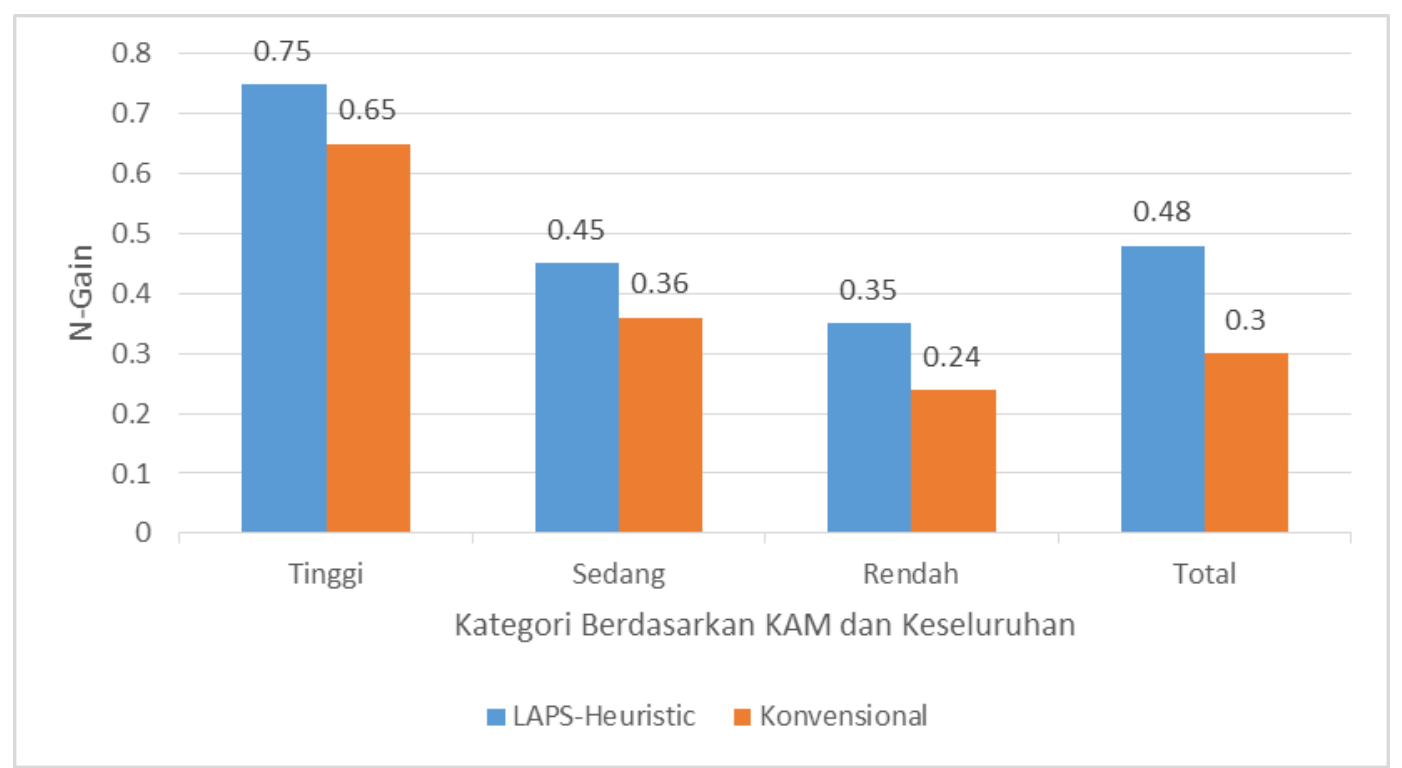

Gambar 1. Rerata Peningkatan Kemampuan Pemecahan Masalah Matematis menurut Kelompok Pembelajaran, Kemampuan Awal Matematis, dan Data Total

Rerata postes kelas eksperimen dengan model LAPS-Heuristic dengan pendekatan Open-Ended sebesar 22,39 sedangkan rerata postes kelas konvensional sebesar 18,95. Hal ini menunjukkan bahwa pencapaian kemampuan penalaran matematis siswa ditinjau secara keseluruhan untuk kelas eksperimen lebih baik daripada kelas kontrol. Pada kategori KAM rendah diperoleh rerata postes kelas eksperimen 18,14 dan rerata postes kelas kontrol 12,5. Hal ini menunjukkan bahwa pencapaian kemampuan penalaran matematis ditinjau secara KAM rendah untuk kelas eksperimen lebih baik daripada kelas kontrol. Selanjutnya, rerata postes untuk semua kategori KAM pada kelas ekperimen maupun pada kelas kontrol diperoleh bahwa rerata skor postes ditinjau secara KAM untuk kelas eksperimen lebih baik daripada kelas kontrol. Untuk penyebaran kemampuan penalaran matematis setelah adanya pembelajaran, kelas kontrol lebih menyebar dibandingkan kelas eksperimen karena simpangan baku kelas kontrol lebih besar daripada kelas eksperimen.

Berdasarkan Tabel 3 di atas diperoleh rerata gain kemampuan penalaran matematis siswa apabila ditinjau dari kategori KAM, nampak bahwa KAM tinggi siswa kelas eksperimen mendapat rerata sebesar 0,75 dan siswa kelas kontrol sebesar 0,59. Data tersebut menunjukkan bahwa gain kedua kelas relatif berbeda, yaitu tinggi untuk kelas 
eksperimen dan sedang untuk kelas kontrol, sehingga pembelajaran model LAPS-Heuristic dengan pendekatan Open-Ended memberikan kontribusi yang cukup baik dalam perkembangan kemampuan penalaran matematis siswa pada KAM tinggi.

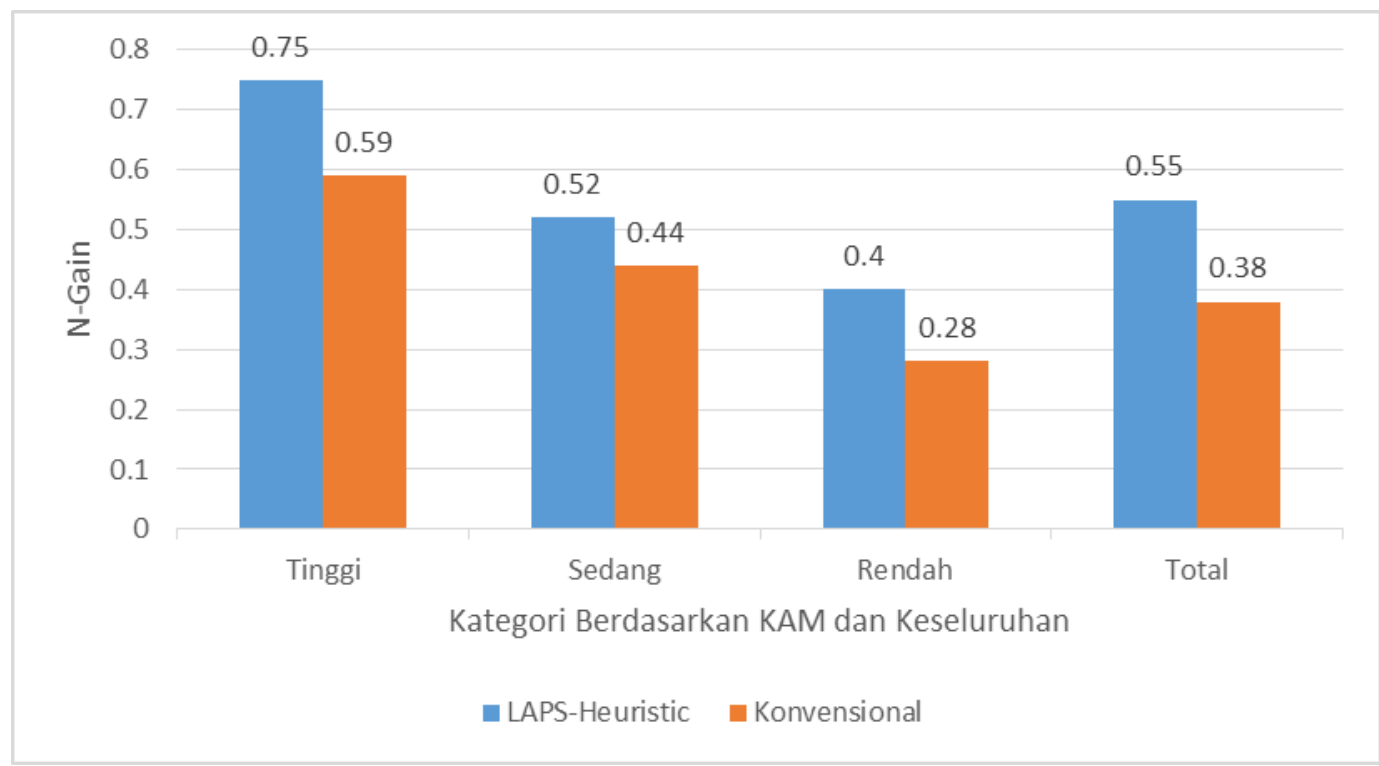

Gambar 2 Rerata Peningkatan Kemampuan Penalaran Matematis menurut Kelompok Pembelajaran, Kemampuan Awal Matematis, dan Data Total

\section{Kemampuan Pemecahan Masalah dan Penalaran Matematis}

Kemampuan pemecahan masalah dan penalaran matematis diperoleh melalui pretes dan postes. Dari skor pretes dan postes selanjutnya dihitung gain ternormalisasi (N-gain) kemampuan pemecahan masalah dan penalaran matematis pada kelas eksperimen yang mendapat pembelajaran model LAPS-Heuristic dengan pendekatan Open-Ended maupun kelas kontrol yang mendapat pembelajaran konvensional. Analisis skor pretes menggunakan uji kesamaan pretes. Uji kesamaan pretes bertujuan untuk memperlihatkan bahwa apakah kemampuan awal kedua kelas sama atau berbeda signifikan. Sebelum data dianalisis terlebih dahulu dilakukan uji prasyarat analisis statistik yaitu uji normalitas dan uji homogenitas.

Untuk mengetahui peningkatan kemampuan pemecahan masalah dan penalaran matematis pada siswa yang pembelajarannya menggunakan model pembelajaran model LAPS-Heuristic dengan pendekatan Open-Ended dan siswa yang pembelajarannya menggunakan model pembelajaran konvensional akan dilakukan dengan menguji perbedaan rerata gain ternormalisasi. Adapun uji statistik yang digunakan untuk membuktikan hipotesis yang menyatakan "Peningkatan kemampuan pemecahan masalah dan penalaran matematis siswa yang memperoleh pembelajaran melalui model 
pembelajaran LAPS-Heuristic dengan pendekatan open-ended lebih baik daripada siswa yang memperoleh pembelajaran konvensional" yaitu uji perbedaan rerata skor N-gain. Sebelum malakukan uji perbedaan rerata skor $\mathrm{N}$-gain terlebih dahulu dilakukan uji prasyarat normalitas dan homogenitas. Rumusan hipotesis statistik adalah sebagai berikut: $H_{0}: \mu_{1} \leq \mu_{2}$

Peningkatan kemampuan pemecahan masalah dan penalaran matematis siswa yang memperoleh pembelajaran melalui model pembelajaran LAPS-Heuristic dengan pendekatan open-ended tidak lebih baik daripada siswa yang memperoleh pembelajaran konvensional.

\section{$H_{1}: \mu_{1}>\mu_{2}$}

Peningkatan kemampuan pemecahan masalah dan penalaran matematis siswa yang memperoleh pembelajaran melalui model pembelajaran LAPS-Heuristic dengan pendekatan open-ended lebih baik daripada siswa yang memperoleh pembelajaran konvensional.

dengan

$\mu_{1}$ : Rara-rata skor N-gain pemecahan masalah dan penalaran matematis siswa yang melalui pembelajaran melalui model pembelajaran LAPS-Heuristic dengan pendekatan open-ended.

$\mu_{2}$ : Rata-rata skor $\mathrm{N}$-gain pemecahan dan penalaran matematis siswa yang melalui pembelajaran dengan model pembelajaran konvensional.

Berdasarkan uji prasyarat statistik maka dilakukan uji kesamaan rerata skor postes pemecahan masalah dan penalaran dilakukan dengan menggunakan uji-t. Hipotesis di atas, merupakan hipotesis satu arah, karena perhitungan menggunakan SPSS maka kriteria pengujian hipotesis menurut Whidiarso (Ramdhani, 2012) jika $\frac{1}{2} \operatorname{sig} .(2-\operatorname{arah})=\operatorname{sig} .(1-\operatorname{arah})>0,05$ maka $\mathrm{H}_{0}$ diterima, sedangkan jika sebaliknya maka $\mathrm{H}_{0}$ ditolak. Hasil perhitungan uji perbedaan rerata skor $\mathrm{N}$-gain disajikan dalam Tabel 4 dan 5 berikut:

Tabel 4. Uji Kesamaan Rerata Skor N-gain Pemecahan Masalah Matematis

\begin{tabular}{ccccccc}
\hline Kelas & T & Df & $\begin{array}{c}\text { Sig. (2- } \\
\text { tailed) }\end{array}$ & $\begin{array}{c}\text { Sig. (1- } \\
\text { tailed) }\end{array}$ & Ket. & Kesimpulan \\
\hline $\begin{array}{c}\text { Eksperimen } \\
\text { Kontrol }\end{array}$ & 5,175 & 86 & 0,000 & 0,000 & $\mathrm{H}_{0}$ ditolak & Lebih Baik \\
\hline
\end{tabular}


Pada Tabel 4 terlihat nilai sig. (1-tailed) $<\alpha$ yaitu 0,000. Hal ini menunjukkan bahwa $\mathrm{H}_{0}$ ditolak, artinya peningkatan kemampuan pemecahan masalah matematis siswa kelas eksperimen lebih baik daripada kelas kontrol. Dengan demikian terbukti bahwa hipotesis yang menyatakan bahwa peningkatan kemampuan pemecahan masalah matematis siswa yang mendapat pembelajaran melalui model pembelajaran LAPS-Heuristic dengan pendekatan open-ended lebih baik daripada siswa yang mendapat pembelajaran konvensional.

Tabel 5. Uji Kesamaan Rerata Skor N-gain Penalaran Matematis

\begin{tabular}{ccccccc}
\hline Kelas & T & Df & $\begin{array}{c}\text { Sig. (2- } \\
\text { tailed) }\end{array}$ & $\begin{array}{c}\text { Sig. (1- } \\
\text { tailed) }\end{array}$ & Ket. & Kesimpulan \\
\hline $\begin{array}{c}\text { Eksperimen } \\
\text { Kontrol }\end{array}$ & 5,890 & 86 & 0,000 & 0,000 & $\mathrm{H}_{0}$ ditolak & Lebih Baik \\
\hline
\end{tabular}

Pada Tabel 5 terlihat nilai sig. (1-tailed) $<\alpha$ yaitu 0,000. Hal ini menunjukkan bahwa $\mathrm{H}_{0}$ ditolak, artinya peningkatan kemampuan Penalaran matematis siswa kelas eksperimen lebih baik daripada kelas kontrol. Dengan demikian terbukti bahwa hipotesis yang menyatakan bahwa peningkatan kemampuan Penalaran matematis siswa yang mendapat pembelajaran melalui model pembelajaran LAPS-Heuristic dengan pendekatan open-ended lebih baik daripada siswa yang mendapat pembelajaran konvensional.

Selanjutnya, analisis perbedaan peningkatan kemampuan pemecahan masalah dan penalaran siswa KAM tinggi, sedang, rendah pada kelas eksperimen dilakukan menggunakan ANOVA satu jalur, sebab peubah bebas yang diperhatikan hanya satu, yaitu tingkat kemampuan awal matematis siswanya saja

Kemudian kita menggunakan uji statistik ANOVA satu jalur dari N-Gain kemampuan pemecahan masalah dan penalaran matematis pada taraf signifikan $\alpha=0,05$.

Rumusan hipotesis untuk uji homogenitas adalah sebagai berikut:

$\mathrm{H}_{0}: \mu_{1}=\mu_{2}=\mu_{3}$

$\mathrm{H}_{1}$ ₹ paling sedikit ada satu tanda sama dengan yang tidak dipenuhi

Tabel 6. Uji ANOVA Satu Jalur N-Gain (KAM) Kemampuan Pemecahan Masalah Matematis Kelas Eksperimen

\begin{tabular}{|c|c|c|c|c|c|c|}
\hline $\begin{array}{c}\text { Sumber } \\
\text { Perbedaan }\end{array}$ & $\begin{array}{c}\text { Jumlah } \\
\text { Kuadrat }\end{array}$ & Df & $\begin{array}{c}\text { Rerata } \\
\text { Jumlah } \\
\text { Kuadrat }\end{array}$ & $\mathbf{F}$ & Sig. & Kesimpulan \\
\hline $\begin{array}{l}\text { Antar } \\
\text { Kelompok } \\
\text { Inter }\end{array}$ & 0,290 & 41 & $\begin{array}{l}0,145 \\
0,002\end{array}$ & 65,120 & 0,000 & $\begin{array}{c}\text { Terdapat } \\
\text { Perbedaan }\end{array}$ \\
\hline
\end{tabular}


Kelompok

Tabel 7. Uji ANOVA Satu Jalur N-Gain (KAM) Kemampuan Penalaran Matematis Kelas Eksperimen

\begin{tabular}{|c|c|c|c|c|c|c|}
\hline $\begin{array}{c}\text { Sumber } \\
\text { Perbedaan }\end{array}$ & $\begin{array}{l}\text { Jumlah } \\
\text { Kuadrat }\end{array}$ & df & $\begin{array}{c}\text { Rerata } \\
\text { Jumlah } \\
\text { Kuadrat }\end{array}$ & $\mathbf{F}$ & Sig. & Kesimpulan \\
\hline Antar & 0,412 & 2 & 0,206 & & & \\
\hline $\begin{array}{l}\text { Kelompok } \\
\text { Inter } \\
\text { Kelompok }\end{array}$ & 0,176 & 41 & 0,004 & 47,979 & 0,000 & $\begin{array}{l}\text { Terdapat } \\
\text { Perbedaan }\end{array}$ \\
\hline
\end{tabular}

Dari Tabel 6 dan 7 tersebut terlihat bahwa N-Gain memiliki nilai sig. $<\alpha=0,05$ yaitu sebesar 0,000 untuk peningkatan kemampuan pemecahan masalah dan penalaran matematis sehingga $\mathrm{H}_{0}$ ditolak, artinya terdapat perbedaan peningkatan kemampuan pemecahan masalah dan penalaran matematis dilihat dari kategori KAM siswa. Selanjutnya, untuk melihat perbedaan peningkatan tiap kategori KAM dilakukan uji Scheffe

Berdasarkan analisis data hasil penelitian yang telah disajikan, berikut ini akan diuraikan pembahasan hasil penelitian disertai beberapa temuan selama melaksanakan penelitian. Hasil pengamatan sebelum dilakukan pembelajaran model LAPS-Heuristic dengan pendekatan Open-Ended, kegiatan pembelajaran berpusat pada guru (teacher centered). Siswa hanya datang, duduk, dengar, catat dan hafal di kelas sehingga mereka kurang diberi kesempatan untuk mengembangkan ide-ide dalam pikiran mereka guna menyelesaikan soal yang ada, akibatnya kemampuan pemecahan masalah dan penalaran matematis mereka rendah. Sebagai bukti ketika siswa diberi soal yang berbeda dari soalsoal yang pernah diberikan oleh guru, mereka mengalami kesulitan untuk menyelesaikannya. Hal ini dikarenakan mereka tidak memahami permasalahan/soal tersebut, akan tetapi mereka hanya terbiasa menghafal soal saja. Selain itu, ketika siswa diminta membuat model matematika dari soal cerita kebanyakan dari mereka tidak mengerti dan ketika diminta menjelaskan hasil pekerjaannya banyak siswa yang masih kebingungan. Sehingga pada akhirnya hasil belajar mereka rendah. Selain itu, pembelajarannya juga monoton dan tidak mengaktifkan siswa. Peneliti menemukan ada siswa yang tidak bersemangat mengerjakan latihan soal yang diberikan oleh guru. Hal ini disebabkan karena siswa tidak mengerti materi yang disampaikan oleh guru. Bukti lainnya 
adalah ketika siswa mengalami kesulitan, mereka lebih memilih untuk ngobrol dengan temannya dari pada bertanya kepada guru.

Pada penelitian ini diketahui bahwa perbedaan rata-rata kemampuan pemecahan masalah dan penalaran matematis siswa antara kelas eksperimen dan kelas kontrol menunjukkan bahwa pembelajaran matematika model LAPS-Heuristic dengan pendekatan Open-Ended lebih baik dari pada pembelajaran dengan metode konvensional yang diterapkan di sekolah tersebut. Setelah dilakukan pembelajaran sebanyak enam kali pertemuan pada kedua kelompok dengan pendekatan yang berbeda, selanjutnya diberikan postes untuk mengetahui kemampuan pemecahan masalah dan penalaran matematis. Kemudian dilakukan analisis terhadap data postes dan data gain kedua kelas (kelas eksperimen dan kelas kontrol). Skor postes kemampuan pemecahan masalah matematis siswa kelas eksperimen diperoleh rata-rata 12,39 dengan simpangan baku 2,37. Pada kelas kontrol diperoleh skor rata-rata kemampuan pemecahan masalah matematis siswa 11,18 dengan simpangan baku 2,31. Kemudian untuk skor postes kemampuan penalaran matematis siswa kelas eksperimen diperoleh rata-rata 22,39 dengan simpangan baku 3,36. Pada kelas kontrol diperoleh skor rata-rata kemampuan penalaran matematis siswa 18,95 dengan simpangan baku 3,68. Dari hasil pengujian rata-rata skor postes kemampuan pemecahan masalah dan penalaran matematis siswa kedua kelas (kelas eksperimen dan kelas kontrol) pada taraf signifikan 0,05 dapat disimpulkan bahwa terdapat perbedaan yang signifikan. Berdasarkan analisis data melalui uji-t mengenai kemampuan pemecahan masalah dan penalaran matematis siswa menurut kemampuan awal matematika siswa dan kelas model pembelajaran disimpulkan bahwa terdapat perbedaan yang signifikan kemampuan pemecahan masalah dan penalaran matematis antara siswa yang memperoleh pembelajaran model LAPS-Heuristic dengan pendekatan Open-Ended dengan siswa yang memperoleh pembelajaran matematika secara konvensional, ditinjau dari kemampuan awal siswa (tinggi, sedang, dan rendah).

Pembelajaran model LAPS-Heuristic dengan pendekatan Open-Ended dalam penelitian ini terdiri dari empat tahapan pembelajaran yang diadaptasi dari pendapat para ahli dimana permasalahan yang dimunculkan bersifat terbuka, yaitu: menemukan masalah, menyusun strategi penyelesaian masalah, menentukan keuntungan dan kerugian penggunaan strategi tersebut, dan mencari solusi. Pada proses pembelajarannya siswa diberikan Lembar Kerja Siswa (LKS) yang berisi tahapan-tahapan tersebut. Tahapan pertama dalam pembelajaran model LAPS-Heuristic dengan pendekatan Open-Ended yaitu 
menemukan permasalahan yang dihadapi. Siswa diberikan suatu ilustrasi atau masalah diawal, kemudian siswa diminta untuk menuliskan informasi apa saja yang terdapat dalam ilustrasi tersebut. Tahapan ini melatih siswa untuk dapat mengungkapkan situasi atau permasalahan yang terdapat dalam ilustrasi sehingga dapat menyelesaikan masalah tersebut sesuai dengan konteks permasalahan. Siswa juga diberikan keleluasaan untuk menentukan strategi apa yang digunakan dalam penyelesaian permasalahan tersebut. Dalam tahapan ini indikator pemecahan masalah yang dikembangkan yaitu memahami masalah. Untuk kemampuan penalaran indikator yang dikembangkan adalah penalaran logis, mampu mengidentifikasi alasan logis dari serangkaian informasi atau kasus yang diperlukan untuk menyelesaikan soal

Tahapan yang kedua yaitu menentukan cara menyelesaikan masalah. Pada tahapan ini siswa dilatih untuk dapat menentukan cara penyelesaian masalah sehingga siswa dapat menentukan konsep apa yang digunakan untuk menyelesaikan permasalahan. Pada tahapan ini indikator pemecahan masalah yang dikembangkan adalah menyusun strategi. Untuk kemampuan penalaran indikator yang dikembangkan adalah penalaran logis dan menggunakan pola hubungan untuk menganalisis situasi, dan menyusun konjektur, Tahapan ketiga yaitu menentukan keuntungan dan kerugian dari strategi yang kita dilaksanakan dalam pemecahan persoalan. Tahapan ini memungkinkan siswa membangun pengetahuannya dan mengaitkannya dengan pengetahuan matematis diluar materi pembelajaran yang sedang dipelajari. Tahapan keempat adalah memperoleh solusi dari permasalahan tersebut. Pada tahapan ini siswa juga dilatih untuk membuat langkahlangkah penyelesaian masalah beserta alasan-alasan yang mendukung, untuk akhirnya ditarik sebuah kesimpulan. Indikator kemampuan pemecahan masalah yang dikembangkan dalam tahapan ini yaitu melaksanakan strategi dan memeriksa hasil pengerjaan. Indikator penalaran yang dikembangkan pada tahapan ini adalah melaksanakan perhitungan berdasarkan rumus dan aturan tertentu dan juga memperkirakan jawaban, solusi atau kecenderungan : interpolasi dan ekstrapolasi.

\section{KESIMPULAN}

Berdasarkan hasil analisis, temuan, dan pembahasan yang telah disajikan pada bab sebelumnya, diperoleh kesimpulan sebagai berikut: (1) Peningkatan kemampuan pemecahan masalah matematis siswa yang memperoleh pembelajaran melalui model pembelajaran LAPS-Heuristic dengan pendekatan open-ended lebih baik daripada siswa 
yang memperoleh pembelajaran konvensional; (2) Peningkatan kemampuan penalaran matematis siswa yang memperoleh pembelajaran melalui model pembelajaran LAPSHeuristic dengan pendekatan open-ended lebih baik daripada siswa yang memperoleh pembelajaran konvensional; (3) Terdapat perbedaan peningkatan kemampuan pemecahan masalah matematis siswa yang menggunakan model pembelajaran LAPS-Heuristic dengan pendekatan open-ended dilihat dari kemampuan siswa (tinggi, sedang dan rendah); (4) Terdapat perbedaan peningkatan kemampuan penalaran matematis siswa yang menggunakan model pembelajaran LAPS-Heuristic dengan pendekatan open-ended dilihat dari kemampuan siswa (tinggi, sedang dan rendah).

\section{DAFTAR PUSTAKA}

Hudoyo, H. (2003). Pengembangan Kurikulum dan Pembelajaran Matematika. Malang: JICA-Universitas Negeri Malang.

Meltzer. (2002). The Relationship Between Mathematics Preparation and Conceptual Learning Gains in Physic: A Possible "Hidden in Variable" in Diagnostic Pretest Score. Department of Physic and Astronomyz: IOWA State University, Ames, Iowa. Diunduh dari: http://www.physic.iastate.edu/per/doc/Addendum on normalized gain. [12 Juli 2016].

National Council of Teachers of Mathematics. (2000). Principles and Standards for School Mathematics. Reston, VA: NCTM.

Permendiknas. (2006). Lampiran Peraturan Menteri Pendidikan Nasional Republik Indonesia Nomor 22 Tahun 2006 Tentang Standar Isi. Jakarta: BSNP.

Polya, G. (1973). How to Solve It, a New Aspect of Mathematical Method. New Jersey: Princenton University Press.

Ramdhani, S. (2012). Pembelajaran Matematika dengan Pendekatan Problem Possing untuk Meningkatkan Kemampuan Berpikir Kritis Matematis Siswa SMA. Tesis pada Sekolah Pascasarjana UPI. Tidak diterbitkan.

Ruseffendi, E. T. (2006). Pengantar Kepada Membantu Guru Mengembangkan Kompetensinya dalam Pengajaran Matematika untuk Meningkatkan CBSA. Bandung: Tarsito.

Suherman, E. (2003). Strategi Pembelajaran Matematika Kontemporer.(Common Textbook). Bandung: JICA-Universitas Pendidikan Indonesia.

Suherman, E. (2004). Model-Model Pembelajaran Matematika. Makalah (Disajikan dalam Acara Diklat Pembelajaran bagi Guru-Guru Pengurus MGMP Matematika di LPMP Jawa Barat tanggal 10 Desember 2004). Bandung: Tidak diterbitkan.

Sumarmo, U. (2004). Pembelajaran Matematika Untuk Mendukung Pelaksanaan Kurikulum Berbasis Kompetensi. Laporan Penelitian. FPMIPA UPI Bandung: Tidak diterbitkan. 